\title{
Evolution of urban hierarchies under globalisation in Western and Eastern Europe
}

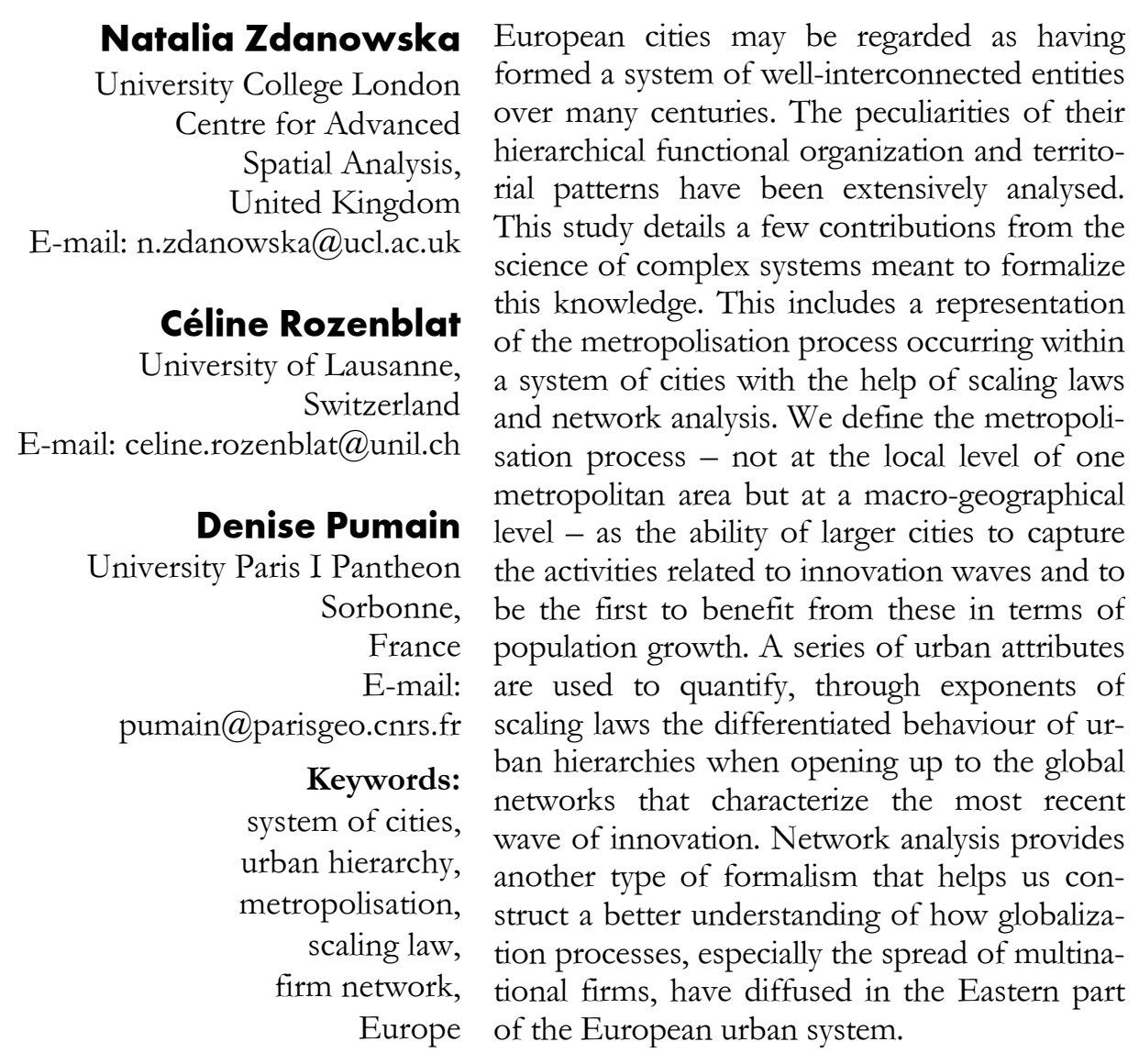

Natalia Zdanowska

sity College London

Spatial Analysis,

Céline Rozenblat

University of Lausanne,

Switzerland

E-mail: celine.rozenblat@unil.ch
European cities may be regarded as having formed a system of well-interconnected entities over many centuries. The peculiarities of their hierarchical functional organization and territorial patterns have been extensively analysed. This study details a few contributions from the science of complex systems meant to formalize representation the metropolisation process occurring within sation process - not at the local level of one metropolitan area but at a macro-geographical - as the ability of larger cities to capture the activities related to innovation waves and to be the first to benefit from these in terms of population growth. A series of urban attributes are used to quantify, through exponents of networks that characterize the most recent wave of innovation. Network analysis provides another type of formalism that helps us construct a better understanding of how globalization processes, especially the spread of multinaof the European urban system.

\section{Introduction}

This study provides a new elaboration from a set of investigations about the evolution of European cities. We define a system of cities as a set of intensely connected cities whose evolutions became interdependent and they co-evolve through their connections within multiple networks (Pumain 1997, Peris et al. 2018). We do not propose an entire review of this question, which is already well-documented by statisticians, demographers, geographers, and historians from Western Europe (e.g. de Vries 1984, Hohenberg-Lees 1995, Hall-Pain 2006, ESPON 2010, Atkinson 2019) and specialists from Eastern Europe (Dziewoński 1953, Korcelli 1992, Musil 1977, Enyedi 1996, Geróházi et al. 2011, Szirmai 2012, Máté et al. 2013, Páthy 2017). We have summarized earlier on how European cities could be considered as

Regional Statistics, Vol. 10. No. 2. 2020: 3-26; DOI: 10.15196/RS100202 
having formed a system over many centuries due to the multiple networks that have developed between them (Kohl 1841, Cattan et al. 1994, Pumain-Saint-Julien 1996, Bretagnolle et al. 2000, Bretagnolle-Pumain 2010). This hypothesis has been revisited many times, emphasizing the diversity of urban spatial patterns (Rozenblat 1995, 2009), the diversity and complementarity of urban attributes and functional trajectories (Rozenblat-Cicille 2003), and the polycentric structure of the system (Rozenblat-Pumain 2018). We focus on the more recent transformations of the European system of cities linked via globalization, especially those that have occurred since Eastern Europe opened up to the market economy in 1990.

Most authors who analyse globalization processes focus on larger cities. Europe is one of the most developed regions of the world. It has been urbanised for a very long time. However, due to the ancient fragmentation of its territory in many states, it does not have very big cities when compared to large Asian countries twice as populous (China and India), or even to less populous countries like the United States, Brazil, or Japan. Therefore it seems opportune to ask how the effects of globalization spread across Europe's urban hierarchy, not only by studying a few large cities but also by considering the system of cities as a whole, including small and medium-sized cities. Based on the evolutionary theory of urban systems (Pumain 1997, 2018), our major hypothesis is that the globalisation trend can be analysed as an innovation wave that challenges cities' capacity for adaptation. This adaptive urban co-evolution usually reinforces the hierarchical inequalities within systems of cities, resulting in a metropolisation trend (Robson 1973, Pred 1977, Pumain-Moriconi-Ebrard 1997, Pumain et al. 2015).

This study first recalls the peculiarities of the hierarchical structure of the system of cities in Europe, including its geographical variations. Then we examine how the recent literature on scaling laws may help in detecting a metropolisation process in urban hierarchies and link them to the hierarchical diffusion of innovation in urban systems, leading us to observe a West-East divide in the metropolisation trend linked to the recent diffusion of global networks within the European urban system (Rozenblat-Melançon 2013, Rozenblat-Pumain 1993, 2007). Finally, we deepen the interpretation of this last trend by conducting a zoom analysis on how multinational networks selected cities in Central and Eastern Europe after 1990 (Zdanowska 2018). The conclusion is that path dependence effects are important in urban evolution and offer a powerful explanation of the persistency of hierarchical and geographical peculiarities within systems of cities.

\section{Hierarchical and geographical structuration of the European system of cities}

The urban transition that massively moved populations from rural to urban areas starting with the demographic transition and industrial revolution in Europe around the end of the $18^{\text {th }}$ century (Zelinsky 1971) has spread throughout all parts of the

Regional Statistics, Vol. 10. No. 2. 2020: 3-26; DOI: 10.15196/RS100202 
world. The economic, technical, and social constraints that are now exerted on urban development seem to prevail globally, in all cities (World Bank 2009). This trend towards globalising urban issues is being amplified through the requirements and concerns associated with climatic changes and the mitigating transitional policies aimed at renewable energies and, more broadly, at environmental protection. However, the spatial structures within and between cities are still dependent on the long history of settlement systems. Traces of ancient spatial organization still differentiate the European urban system from others in the world and, to a lesser extent, differentiate between Western and Eastern Europe (Bretagnolle et al. 2000, Rozenblat-Pumain 2018). This is a very good example of 'historical chaining' or 'path dependence' in complex systems. This dynamic feature is very important because it determines the solutions that can be adopted in order to help cities adapt to socioeconomic and technological transformation (UN-Habitat 2016).

\section{Europe is a continent of small and mid-sized towns}

Europe is a region of small towns due to an old settlement system, in which cities have developed relatively continuously with modes of spatial interaction governed by slow speeds and thus under strong proximity constraints. European urban agglomerations larger than 10,000 inhabitants are spaced an average of $15 \mathrm{~km}$ apart. As a result, almost half of Europe's population lives in agglomerations of fewer than 500,000 inhabitants, which makes Europe markedly different from the other continents (see Table 1). Conversely, the share of the population living in cities larger than 5 million inhabitants is rather small, lower than $5 \%$, whereas this figure ranges from $10 \%$ to $15 \%$ in parts of the world with similar high rates of urbanization - in other words, where at least three quarter of the population is urban; this proportion will probably be reached quickly in the next two or three decades by countries in Asia and Africa that are undergoing accelerated urbanization.

Distribution of total population in size classes of cities*

Table 1

\begin{tabular}{l|c|c|c|c|c}
\multicolumn{1}{c|}{ Size of cities } & $<500000$ & $\begin{array}{c}500000- \\
5 \text { million }\end{array}$ & $>5$ millions & $\begin{array}{c}\text { Rural } \\
\text { population }\end{array}$ & Total \\
\hline Latin America & 36 & 22 & 15 & 27 & 100 \\
North America & 30 & 35 & 12 & 23 & 100 \\
Europe & 47 & 22 & 4 & 27 & 100 \\
Asia & 20 & 14 & 3 & 63 & 100 \\
Africa & 23 & 11 & 390
\end{tabular}

* Cities considered urban agglomerations.

Source: United Nations (2014).

Regional Statistics, Vol. 10. No. 2. 2020: 3-26; DOI: 10.15196/RS100202 
As a consequence, Europe has only two megacities (cities larger than 10 million inhabitants), Paris and London, and the continent does not need to manage gigantic human concentrations such as those that have developed in the megalopolises of Northeast America between Boston and Washington, or in Japan from Tokyo to Osaka, or those developing within the large Chinese deltas, each grouping now containing from 40 to more than 100 million inhabitants. Moreover, Asia is generating unprecedented mixes and nesting of urban habitats and manufacturing activities with rural ones, generating a specific pattern between cities and the countryside termed 'desakota' by McGee (2009). Such desakota forms are hardly found in the peri-urban areas of major European agglomerations.

\section{A continent of moderately dense cities yet highly structured in systems of cities}

Europe is different from the other continents not only in the distribution of its cities but also in its average urban densities. Europe's average urban density levels are intermediate between the extreme dilution of North American cities and the high concentrations of Asian cities. Urban planner Alain Bertaud (2004) has calculated average densities for about 50 millionaire cities in the world by dividing their populations by the built-up surfaces measured on satellite images (these measurements thus define 'urban morphological agglomerations'). The order of magnitude of these average densities is about 2,000 inhabitants per $\mathrm{km}^{2}$ for North American cities, 10,000 to 40,000 for Asian cities, and 4,000 for European cities.

The built-up space of cities is organized with a more or less regular reduction in the intensity of land use from their centre to their periphery. This is due to the high social value of their centres, which are places of maximum accessibility and high identity prestige for businesses and residents. This form of 'urban field' is observed everywhere in the world but with large variations in intensity: Centre-periphery contrasts are accentuated in Asia and very weak in North America, while European cities are in an intermediate position. Strong urban density gradients in Europe often correspond to radio-concentric organizational plans, drawn by the access routes to attractive centres in several directions, combined with ring roads installed on ancient fortifications that were periodically enlarged.

This long-recognized form of spatial organization (Bleicher 1892, Clark 1951) has recently been formalised in terms of fractality (Batty-Longley 1994, Frankhauser 1994). The use of CORINE Land Cover images has made it possible to highlight the wide generality of a European model for the organization of built-up areas around urban agglomerations (Guérois 2003). While population densities, and especially urban land prices, draw out forms of centre-periphery decay modelled by negative power laws or exponential functions, the intensity of physical land occupation is distributed according to a double-linear gradient as a function of distance to the city centre. Built-up areas decrease regularly, not only in the densest parts built

Regional Statistics, Vol. 10. No. 2. 2020: 3-26; DOI: 10.15196/RS100202 
in continuity within the core of the agglomerations but also, according to a lower gradient, in peri-urban areas located in radii of 40 to $100 \mathrm{~km}$ depending on the size. Fractal measurements reveal dimensions with values between 1 and 2 for the central zones of built-up urban areas, while the peripheries of large urban areas often have fractal dimensions of between 0 and 1 , according to scattered forms similar to the mathematical model of Cantor dust (Guérois-Pumain 2008).

Does the dual urban building gradient observed from the CORINE Land Cover data foreshadow the emergence of a new urbanization model on the outskirts of cities, or rather the gradual incorporation of these peripheries into the urbanized perimeter? The recent evolution of these gradients would seem to support the second hypothesis: Whatever the size of cities, the highest growth rates of built-up areas are observed at the boundaries of urban agglomerations. In Europe, urban sprawl occurs on the periphery of the zones already built in continuity more often than it colonizes more distant peripheries (Guérois-Pumain 2008, Denis 2020).

\section{Regional variations of urban hierarchies}

European cities exhibit comparable spatial structures at the local level, but there are internal variations in the statistical shape and spatial distribution of urban hierarchies that differentiate among three large urban settlement styles from the West to the East. Figure 1 presents a simple but striking image of both the persistence of the spatial organization of the systems of cities and of the coherence of these forms across scales of geographical space. Céline Rozenblat (1995) has linked European cities larger than 10,000 inhabitants (classified according to a harmonized definition of morphological agglomerations) using segments of varying lengths: less than $25 \mathrm{~km}$ on the first map (see Figure 1A), from $25 \mathrm{~km}$ to $50 \mathrm{~km}$ (see Figure 1B), and between $150 \mathrm{~km}$ and $200 \mathrm{~km}$ for cities 10 times larger (more than 100,000 inhabitants; see Figure 1C). The spectacular result shows the same large territorial areas on each of the maps: to the West, France and Spain, whose territories where centralized long ago in large kingdoms, exhibit a few high urban concentrations and highly contrasting spatial distributions; in the centre, a dense wrap of closer cities characterizes the states (Germany and Italy) whose lack of national unity, which occurred much later, allowed rival cities and the capitals of principalities or bishoprics to develop in competition over a long period (England, although centralized early on, belongs to this diagonal because of the intensity of its industrial revolution, which, in the $19^{\text {th }}$ century, filled the urban void in the centre of the country by creating fairly large cities); Eastern cities are spaced much more evenly, as these regions were urbanized later but were systematically colonized between the $13^{\text {th }}$ and $17^{\text {th }}$ centuries, mostly by religious organisations. This simple representation is testimony to the strength and durability of the spatial integration of the socio-political structures established in urban interactions and the solid coherence of the resulting multiscalar spatial organizations.

Regional Statistics, Vol. 10. No. 2. 2020: 3-26; DOI: 10.15196/RS100202 


\section{Three settlement styles of urban hierarchies in Europe}

Figure 1

Urban agglomerations $>10,000$ inhabitants Urban agglomerations $>100,000$ inhabitants
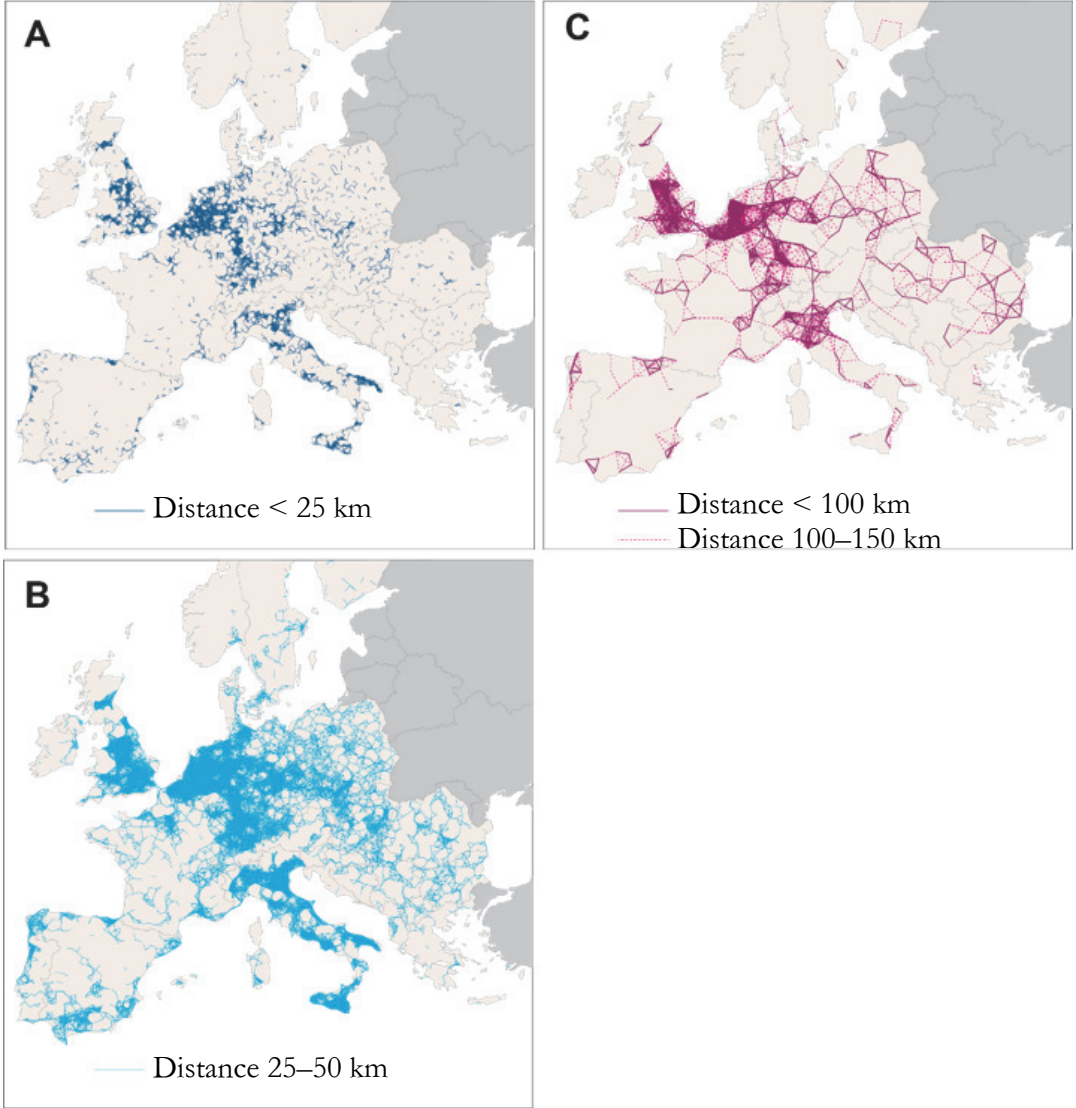

Source: GEOPOLIS, F. Moriconi-Ebrard (1993).

\section{Trends in the recent urban expansion}

We use a restricted concept of metropolisation to describe a fundamental trend in the evolution of every system of cities (Pumain-Moriconi-Ebrard 1997). That systematic trend consists in growing contrasts among city sizes over time that lead to sharper inequalities in urban hierarchies. This trend is theoretically explained by two major processes: i) the hierarchical diffusion of innovations and ii) the space-time contraction (Janelle 1969). The first process leads to a concentration 'from the top' of the hierarchy because the largest cities capture the strongest economic and often demographic growth associated with the first stages of development of new products and services. The second process induces a 'bottom-up simplification' of urban hierarchies because, statistically, smaller cities are penalized in their growth, first in relative 
terms and then in absolute terms, because their catchment areas are bypassed by the expanding range of larger cities linked to faster and more efficient transportation modes (Bretagnolle et al. 1998). This 'simplification from below' of urban hierarchies becomes even more visible when urban growth slows down. Inequalities in size and functional skills widen between cities, leading to new concerns for the fate of small towns, as well as those left behind due to their more or less 'obsolete' specialized activities. Statistically, this devitalization begins in small towns. Support for shrinking cities is beginning to be the subject of remediation policies in Europe (Martinez-Fernandez et al. 2012).

The expansion of European cities continues according to two contradictory processes that depend on the geographical scale of observation. At the national level, the movement of metropolisation produces a relative concentration of the innovative social and productive forms in the largest cities. At the local level, the trend towards urban de-concentration and sprawl has been dominant for at least several decades. This process has a long history, starting early in the largest cities for urbanistic purposes or hygiene reasons (e.g. as early as the end of the $18^{\text {th }}$ century in certain Parisian districts), but has considerably accelerated because of the multiplication of motorized transportation, which allows arbitration in favour of lengthening access distances to the jobs and central services of urbanized areas at the cost of maintaining travel times.

The two contradictory spatial trends in the evolution of cities (metropolisation nationally and urban sprawl locally) must be reconsidered after demographic and urban transitions have been completed. Both transitions have been occurring in developed countries, especially Europe and Japan, since the 19 th $^{\text {century; they began }}$ around 1950 in the developing countries, currently undergoing rapid urbanization. One may wonder if, when urban transition is complete, the metropolisation trend will continue or if a stabilization or even a reversal of that trend is possible. The technical instruments available due to recent developments in studies of urban scaling laws can help us measure more precisely the components of the metropolisation effects according to how urban attributes are changing across the urban hierarchies.

\section{Scaling laws for measuring metropolisation effects and the European West-East divide}

Scaling laws have been the subject of many studies. Physicists have successfully used this formalism to characterize the metabolism of living species (West et al. 1997). More recently, it has been applied to cities (Bettencourt-West 2010, West 2017). A recent special issue of Environment and Planning B (Rybski et al. 2019) offers many examples of applications to urban analysis. We summarize here the results of an experiment conducted on European cities, which develops a theoretical interpretation adapted to objects that, while subject to evolutionary processes, are not biological but social and historical.

Regional Statistics, Vol. 10. No. 2. 2020: 3-26; DOI: 10.15196/RS100202 


\section{An evolutionary interpretation of scaling laws}

Scaling laws describe systematic relationships whose mathematical models are power functions between the size of entities and some of their functional attributes, what biologist d'Arcy Thompson calls 'allometry' (1952). According to physicists, scaling laws reveal physical constraints on the structure and evolution of complex systems. Biologists have identified systematic sub-linear relationships between species' metabolisms and their size, which reveals economies of scale in the construction of biological organisms during their evolution. They were able to explain this in terms of the spatial distribution of energy within organisms through fractal networks (West et al. 1997).

Applied to cities, scaling laws describe the variation of an attribute according to the size of cities, generally measured by their number of inhabitants (Lane et al. 2009). Physicists were surprised to discover that some exponents could be larger than 1 , especially when considering attributes measuring urban productive outputs or concentrations of income and skills. Thus, instead of always considering economies of scale (which can be observed, for example, in urban technical networks), urban scaling laws are able to consider increasing returns to scale, when large cities have developed an attribute to a greater extent than small ones. This growing concentration of attributes along with city size, testifying to metropolisation, has been well known in urban science at least since the first formulations of central place theory to explain the increase in the number, status, and diversity of urban functions along with city size (Reynaud 1841, Christaller 1933, Robic 1982). Physicists translate this into a universal interpretation: 'cities are approximately scaled versions of one anoth$e r^{2}$ (Bettencourt-West 2010). They suggest an explanation in terms of an 'increasing pace of life' as city size increases. Moreover, they infer a longitudinal relationship from transversal data when claiming that 'on average, as city size increases, per capita socioeconomic quantities such as wages, GDP, number of patents produced and number of educational and research institutions all increase by approximately $15 \%$ more than the expected linear growth'. Such extrapolations are contested because ergodicity is not a property of urban dynamics, which is a historical process (Pumain 2012), and because there are no universal values for the empirically observed relationships, which are highly dependent on urban ontologies and measurement contexts and methods (Arcaute et al. 2015).

Explanations that may serve as alternatives to "physical" interpretations of urban scaling laws are related to former urban theories more strongly when they are linked to the processes of urban growth, inter-urban interactions and the spatial diffusion of innovations throughout systems of cities (Pumain et al. 2006). The theory of hierarchical diffusion of innovation (Hägerstrand 1952, Pred 1973, 1977) explains how new activities and social practices are captured first by large cities with the information level, financial support, productive structures, and employment skills required to adopt them at an early stage of development. Although these innovations

Regional Statistics, Vol. 10. No. 2. 2020: 3-26; DOI: 10.15196/RS100202 
tend to percolate down the urban hierarchies, they provide slightly higher benefits in terms of economic returns and social capabilities to the cities that took initial advantage of the adaptation, supporting the historical metropolisation trend that reinforces urban hierarchies. This process was recently accentuated by the acceleration of globalisation, as revealed by experiments on the distribution of economic activities in cities using scaling laws (Paulus 2004, Pumain et al. 2006, Finance 2016). Indeed, the exponents of urban scaling laws vary over time according to the novelty's stage of diffusion in the system of cities: at the beginning of a new innovation wave, exponents increase to above 1 until a maximum is reached; then they stabilize at around 1 when the new activity or social practice becomes common; then they diminish to below 1 when mature activities or residual practices are found in the smallest towns. Thus, we decided that scaling law exponents could be used as reasonable proxies to detect the stage of diffusion of an innovation within a system of cities.

\section{Dual process of innovation diffusion: the West-East divide of Europe}

Previous studies of innovation diffusion in systems of cities have demonstrated that the process differs according to the type of urban hierarchy involved. Sophie Baudet-Michel (2001) observed how business services have percolated in three different systems of cities since the end of the $19^{\text {th }}$ century. She demonstrated that in the first stage the concentration of the activity was higher in systems with a primate city, like France and the UK, whereas eight German metropolises had captured a significant amount of the novelty. In the second stage, the spatial expansion proceeding down the urban hierarchy was much broader in the French than in the German system of cities. Thus, hierarchical diffusion is not an even process according to city size but an adaptation of the whole system of cities that retains the originality of its structural features.

We assume that a variety of globalisation processes integrating European cities in multiple networks can be analysed as an 'innovation wave' that diffuses hierarchically in urban systems. Thus, we decided to analyse which stage had reached the diffusion of globalisation in the European system of cities as a whole and in its parts using scaling laws to provide a measurement of the intensity of metropolisation for a series of urban attributes. Regarding the globalisation process and its effects on European cities, we gathered a number of attributes that were comparable and available around 2010 for as many cities as possible and that many scholars argue indicate their possible or realized participation in global networks. These attributes were indicators of productive capacity, accessibility, attractiveness, centrality in investment networks and centrality in European research space, cultural influence, and access to European institutions. We shall not list again the 25 indicators measured for the 356 largest functional urban areas (in the European Union plus Switzerland and Norway), which are detailed at length in a recent publication (Pumain-

Regional Statistics, Vol. 10. No. 2. 2020: 3-26; DOI: 10.15196/RS100202 
Rozenblat 2019). We provide an illustration of how scaling parameters are estimated in Figure 2 for two among these 25 variables. These two are opposite examples of the different types of qualitative scaling relationships.

The distribution of foreign subsidiaries among European cities is clearly the result of a hierarchical diffusion process at its initial stage: the exponent of 1.33 marks an overconcentration of this connection to the networks of multinational firms that favour the largest cities of the system in the first stage. Conversely, the number of international congresses scales sub-linearly with city sizes with an exponent of 0.58 , indicating a relative overconcentration in smaller towns. This may partly reflect the location of many universities and research centres in smaller towns such as Oxford, Cambridge, Bergen, Lund, Turku, and Heidelberg. Congress activity is also sustained by international networks that may search for locations that are not as prestigious and expensive due to their economic power and that offer other amenities for hosting meetings, such as environmental resources or heritage landmarks.

Our study including the 25 indicators of metropolisation has confirmed the intensity of the penetration of global networks throughout the European urban system (Pumain-Rozenblat 2019). Most of these variables scale super-linearly with city size when adjusted as a power function of the population. This form of super-linear relationship demonstrates the greater ability of the largest cities to capture innovation benefits. In the second step, this study revealed two different stages of metropolisation due to the recent globalisation according to the location of cities in Western and Eastern Europe. While the hierarchical diffusion is almost complete in Western Europe and is reaching many medium-sized cities, the diffusion of global networks is clearly in an earlier stage in Eastern Europe and it is still concentrated in the largest cities, as attested by the much larger scaling exponent values for this region of the system. Thus, the scaling laws reveal a major difference between the Western and Eastern European hierarchical diffusion via globalization that has not been detected before (Pumain-Rozenblat 2019). We now investigate more deeply the evolution process among the Eastern cities. 
Evolution of urban hierarchies under globalisation in Western and Eastern Europe

궁

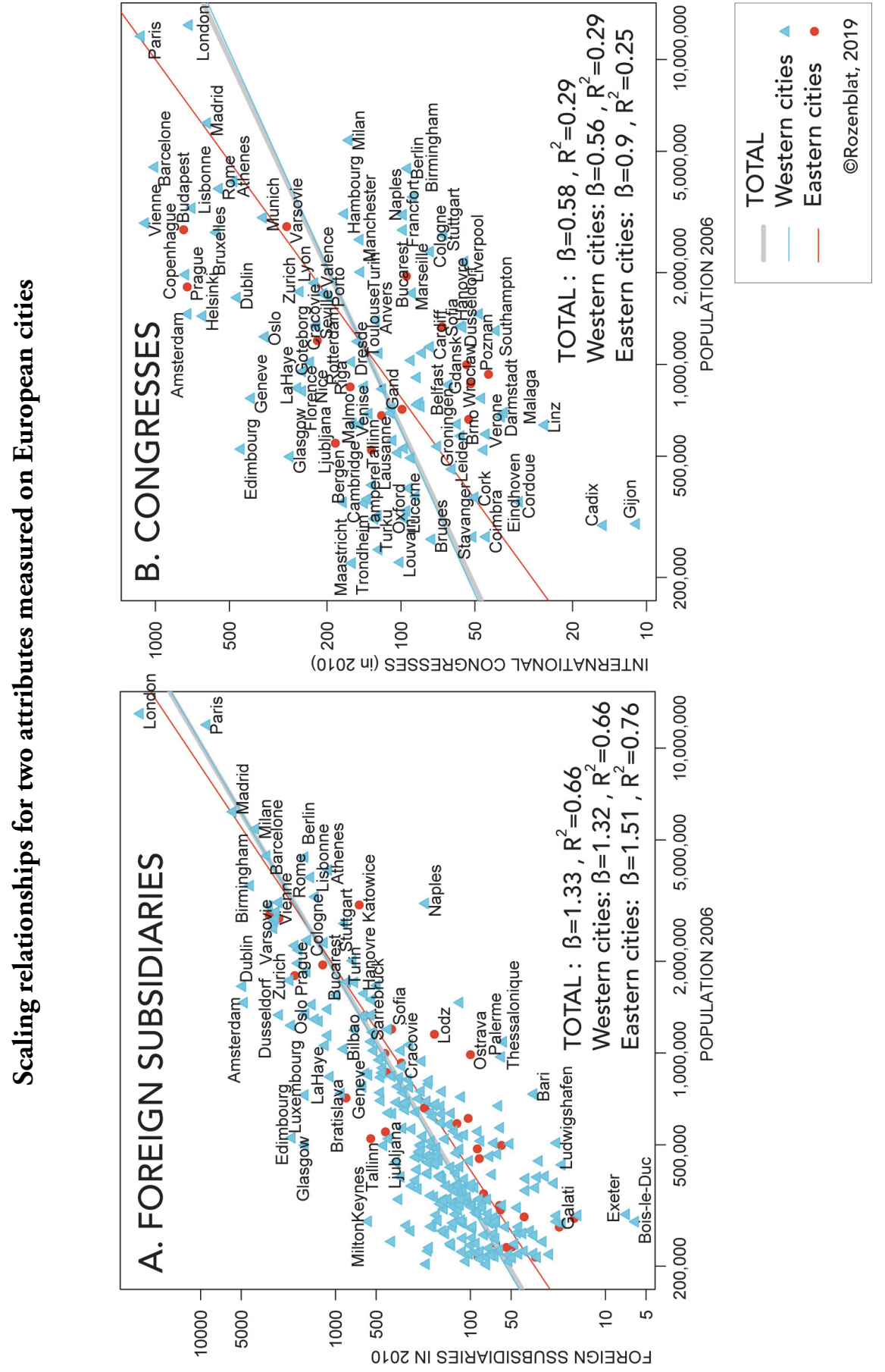

Regional Statistics, Vol. 10. No. 2. 2020: 3-26; DOI: 10.15196/RS100202 


\section{Differentiation within Central and Eastern Europe}

We now focus on the Eastern part of the European Union, where metropolisation and globalisation have been delayed, first due to the more equalitarian urban policies during the socialist period and to their later opening to the market economy. The term 'Central and Eastern Europe', or CEE, ${ }^{1}$ will be used to distinguish the region from Eastern Europe, which sometimes includes Belarus, Ukraine, and Russia in the literature.

Internal West-East gradient in the recent growth impulses probably given by adaptation to globalisation

To complete the vision of a purely hierarchical diffusion process that could be suggested by the high scaling exponents of the globalisation indicators in Eastern Europe, this sub-section tests the hypothesis of a possible uneven development of cities according to their location. These trends have been observed in the literature (Di Lello-Rozenblat 2014, Zdanowska 2015, 2016), but generally at regional level or for particular CEE countries (Lengyel-Szakálné Kanó 2012, Csete-Szabó 2014, Rechnitzer et al. 2019). Our hypothesis is that CEE cities' participation in globalisation has been enhanced or facilitated by their proximity to other European Union countries.

We have estimated this proximity by computing for each city its closest distance in $\mathrm{km}$ to their border with Germany, Austria, or Italy. ${ }^{2}$ All CEE cities were then classified into three classes of geographical longitudes denominated 'Western', 'Central', and 'Eastern' facades. The average distances of cities to the German, Austrian, and Italian borders in each class are $33 \mathrm{~km}, 157 \mathrm{~km}$, and $537 \mathrm{~km}$ respectively (see Figure 3). If our hypothesis is correct, we should observe higher urban growth in the Western class than in the Central and Eastern ones.

\footnotetext{
${ }^{1}$ Understood as the eight post-communist countries that are members of the European Union (Bulgaria, Croatia, the Czech Republic, Hungary, Poland, Romania, Slovakia, and Slovenia).

${ }^{2}$ In technical terms, in ArcMap software, this corresponds to the shortest distance from a point to a borderline, here defined as the shape of the CEE border with Germany, Austria, and Italy.
}

Regional Statistics, Vol. 10. No. 2. 2020: 3-26; DOI: 10.15196/RS100202 
CEE cities' division into three zones of longitude according to their distance from the German, Austrian, or Italian borders

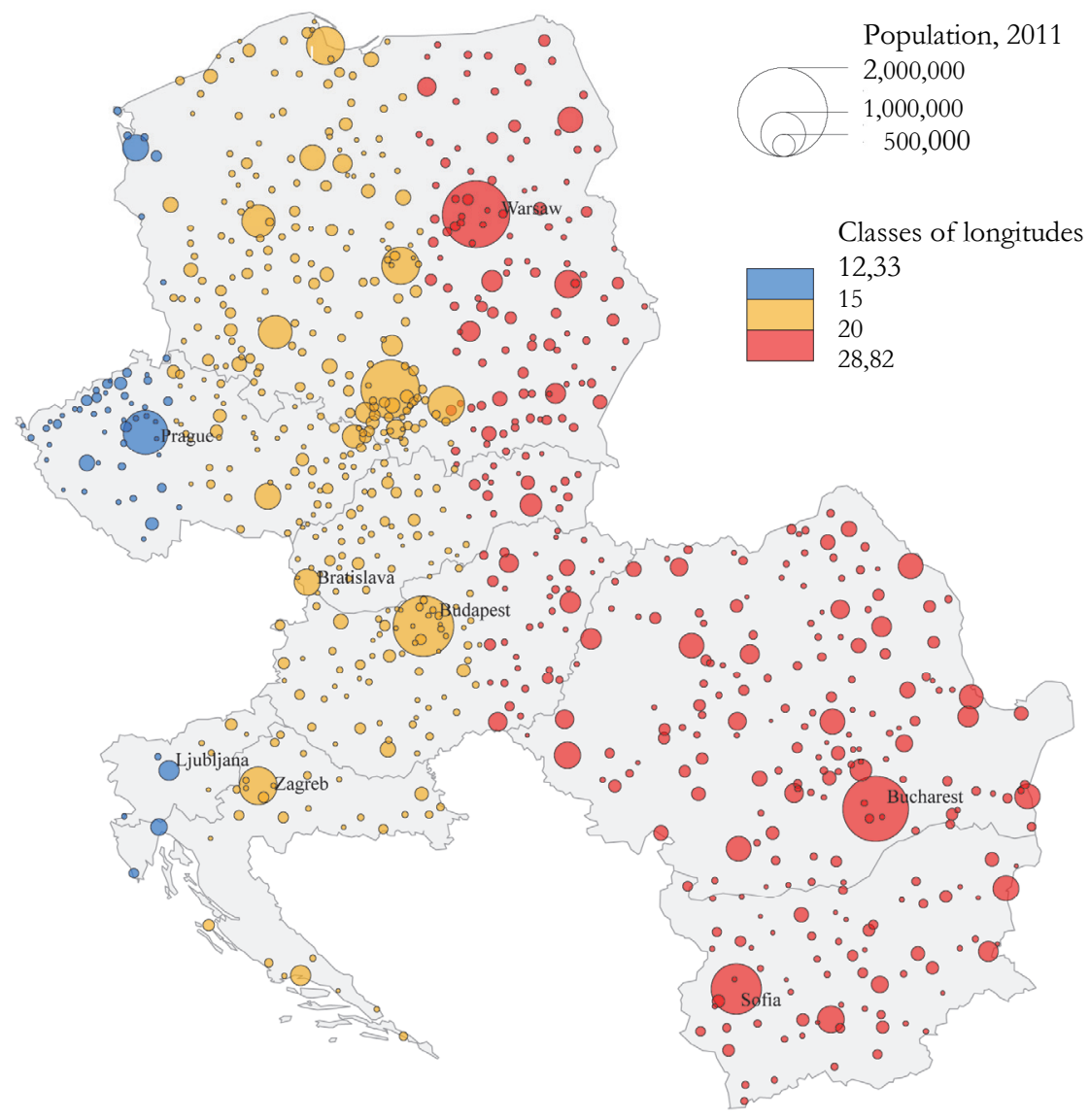

Source: TRADEVE database, Guérois et al. (2019).

We find that, until 1991, the cities located farthest away from the German, Austrian, and Italian borders had the highest growth rates (see Table 2). This situation can be explained by the former wave of the demographic transition changes in cultural and familial behaviour whose spatial diffusion was roughly oriented from the west to the east. After 1991 and its major political changes, these Eastern cities exhibit the most negative growth rates relative to the Western facade. This reversed growth trajectory clearly underlines the extent to which the opening of CEE cities to the market economy and globalisation has created a West-East oriented gradient of urban growth, according to the growth-recovery logics (see Table 2). The political change instituted a complete reversal in the demographic 
behaviour of Western and Eastern cities of the CEE region. This innovation wave may also have deepened the pre-existing contrast between Western regions, which followed the general post-war demographic transition trend early on, and Eastern socialist countries, where this trend has been delayed.

Table 2

\section{Average annual growth rates of cities' population in Central-Eastern Europe per 10 year periods from 1971 to 2011 according to their distance to the border with Germany, Austria, and Italy*}

\begin{tabular}{l|c|c|c|c}
\hline \multicolumn{1}{c|}{ Classes } & $1971-1981$ & $1981-1991$ & $1991-2001$ & 2001-2011 \\
\hline 1. 'Western' facade & 1.57 & 0.71 & 0.02 & 0.05 \\
2. 'Central' façade & 1.82 & 0.99 & -0.01 & 0.12 \\
3. 'East' façade & 2.19 & 1.26 & -0.23 & -0.11
\end{tabular}

* The first, second, and third classes correspond to an average distance of $33 \mathrm{~km}, 157 \mathrm{~km}$, and $537 \mathrm{~km}$ to the nearest border. Thus, class 1 includes the most western cities of Central-Eastern Europe and class 3 the most eastern ones.

Source: Zdanowska (2018).

By contrast, the Czech, Slovak, and Slovenian Class 1 cities nearest to the German, Austrian and Italian borders had lower average growth rates up to 1991. These cities went through the 1990s without experiencing negative growth rates, unlike the cities of classes 2 and 3. The respective rates of the cities of the Eastern facade remained negative until 2011. This confirms the hypothesis of a West-East division of this space in terms of demographic behaviour. The demographic trends of the cities of the Western facade are similar to those of the old settlement systems in Western Europe, characterized by the end of the urban transition, while the cities of the East facade are still pursuing catch-up logics.

The 2000s are marked by the recovery of slightly positive growth rates relative to the previous decade, especially in the Western and Central façades. Some cities, such as Prague, Ljubljana, Varna, and many small and medium-sized cities in Poland were even growing during that period (Zdanowska 2018, Guérois et al. 2019). It seems that they have been able to absorb the external shocks suffered during the 1990s consisting of demographic displacements, intensive forced migrations to the West (Korcelli 1992, Drbohlav 2003, Kaczmarczyk-Okólski 2005), loss of fertility, population ageing, and high unemployment rates (Kovács 2004). We hypothesise that these cities have experienced new metropolitan opportunities and have increased their exchanges with other cities. Several cities that suffered from declining manufacturing sectors in the 1990s (Kiss 2004) have developed a metropolitan potential in the 2000s and are pursuing innovative activities, as in the military and air transport sectors in Rzeszów, Poland (Noworól et al. 2010).

It would seem, therefore, that the degree of urban development among cities in Central and Eastern Europe is related to their geographical proximity to more

Regional Statistics, Vol. 10. No. 2. 2020: 3-26; DOI: 10.15196/RS100202 
economically developed areas such as Germany, Austria, and Italy. There is no correlation between the size of CEE cities and their growth rates, whatever the period, whereas a correlation is found in France (Paulus-Pumain 2000, Paulus 2004) and Russia (Cottineau 2014; see Table 3).

Table 3

Correlations between growth rate and city size for every 10 -year period since 1961 for all cities of the CEE region

\begin{tabular}{c|c|c}
\hline Year-period & $\begin{array}{c}\text { Correlation } \\
\text { coefficient }\end{array}$ & $\mathrm{R}^{2}$ \\
\hline $1961-1971$ & -0.035 & 0.0012 \\
$1971-1981$ & -0.059 & 0.0035 \\
$1981-1991$ & -0.067 & 0.0045 \\
$1991-2001$ & -0.057 & 0.0033 \\
$2001-2011$ & -0.019 & 0.0004
\end{tabular}

Source: Zdanowska (2018).

This result confirms our hypothesis that the resistance to political and economic upheavals is related to proximity to economically more developed cities, which constitute a source of economic exchange opportunities that stimulates growth, as well as the processes of metropolisation.

\section{Economic interactions between the present and the past}

Along the same line of investigation, we checked if the population size of the CEE cities is a key factor in their position within the networks of multinational firms ${ }^{3}$ that are driving the effects of globalisation.

First, a decomposition of the financial ownership linkages led to the identification of capital control chains at three levels, according to the following scheme (see Figure 4). A foreign firm (level N) controls the capital of a firm in a CEE city (level $\mathrm{N}-1$ ). The latter firm owns the capital of another firm (N-2 level). The three-level subnetwork of multinational firms and their ownership links in CEE cities contains 2,312 firms and 1,562 ownership linkages.

${ }^{3}$ The ownership links of firms in 2013 at the city level are sourced from the BvD ORBIS database listing all the companies located outside the CEE that own the capital of CEE companies in all sectors. Information on CEE companies that control the capital of other CEE firms and those outside the CEE is also available.

Regional Statistics, Vol. 10. No. 2. 2020: 3-26; DOI: 10.15196/RS100202 


\section{Decomposition of the capital control links of CEE companies into several levels}

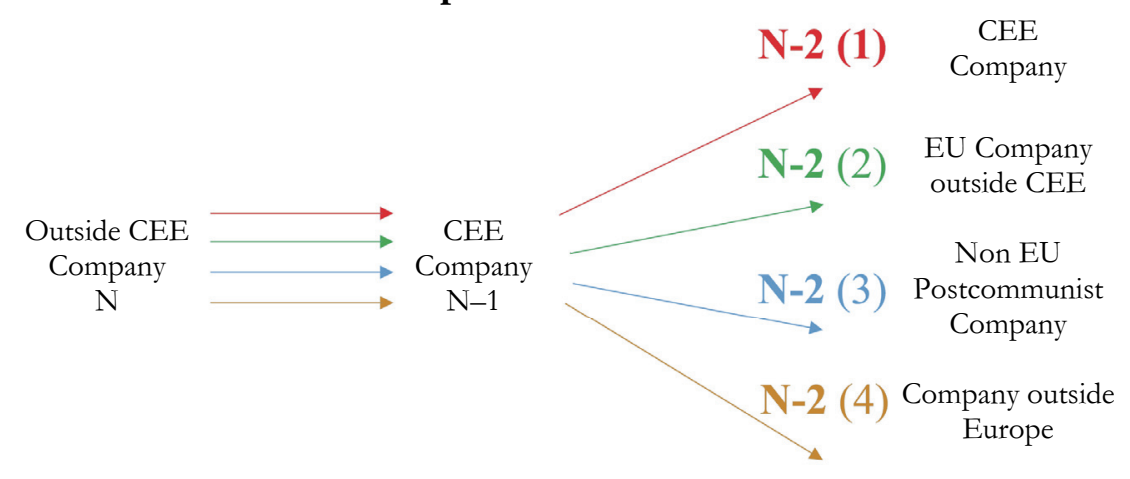

Capital control of more than $50 \%$

Source: Zdanowska (2018).

Then, a correspondence factor analysis was carried out on a matrix of data, counting the number of times a CEE city in N-1 is involved in the four different orientations of capital control links in N-2: in a city from another CEE country (1), in the European Union outside CEE (2), in the post-communist space outside the European Union (3), and outside Europe (4; see Figures 4 and 5).

Figure 5 displays the major geographical orientation of linkages between firms and their subsidiaries for all CEE cities. Some cities display limited participation in globalisation because their firms own links with other CEE cities only - such as Banska Bystrica, Bolatice, Bralin, Breclav or Cesky Tesin (class 1* in Figure 5) - or post-communist ones, such as Belisce, Koper, or Cracow (class $3 *$ in Figure 5). These are mainly small or medium size cities. Conversely, large cities, such as Budapest, Zagreb, and Warsaw have links with European Union areas outside the CEE, CEE areas, and post-communist areas (see Figure 5). This is not the case for all capitals, however. For example, Ljubljana is positioned at links with other CEE cities, and Sofia is present only in post-communist and CEE configurations (see Figure 5). Bucharest is characterised essentially by non-European implications, which can be explained by its geographical position on the outskirts of the European Union.

Regional Statistics, Vol. 10. No. 2. 2020: 3-26; DOI: 10.15196/RS100202 
Figure 5

Major implication of the CEE cities in N-1 according to the four types of orientation of the multilevel links in N-2

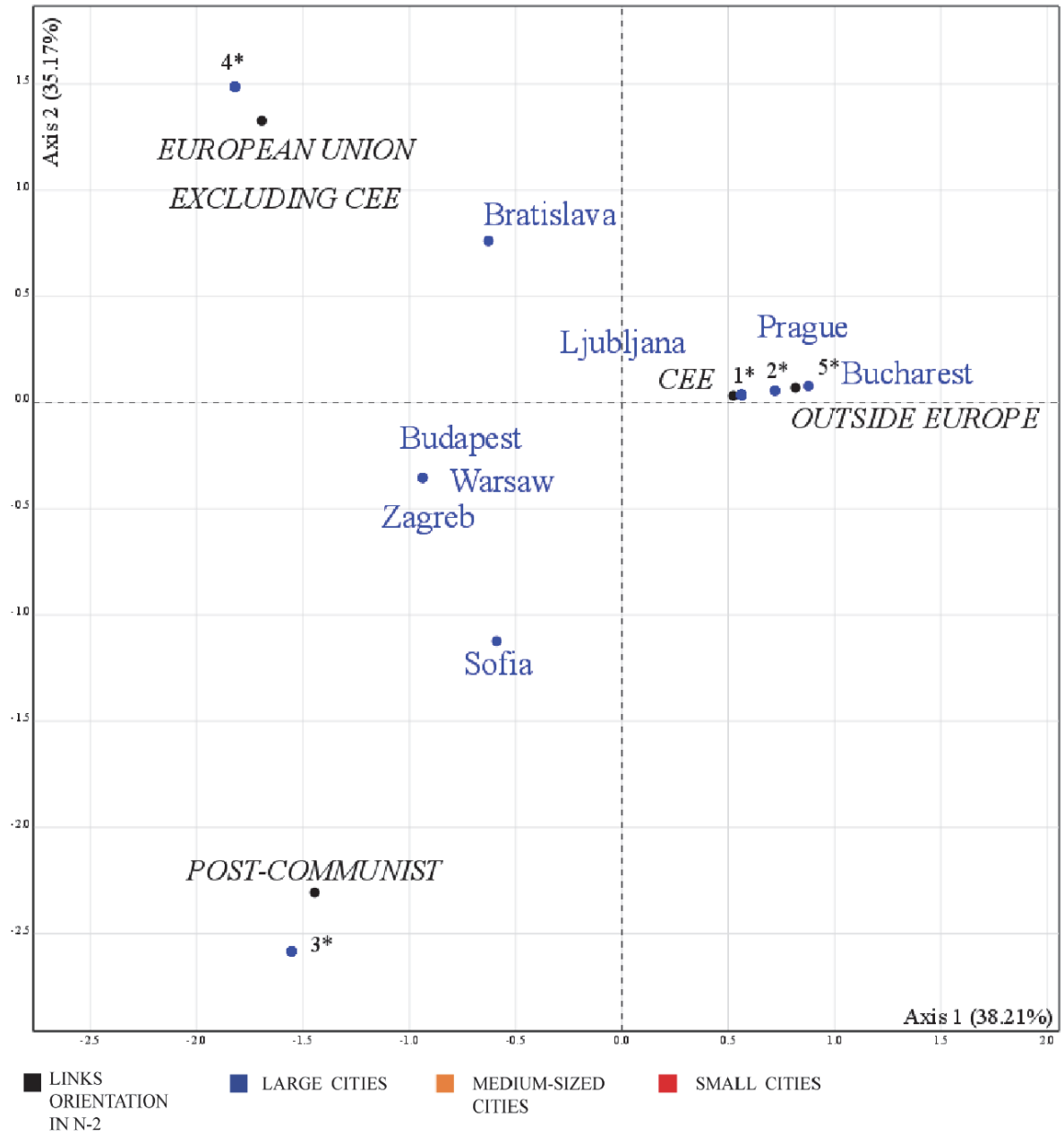

1* Large cities: Brno, Katowice, Lublin; medium-sized cities: Bourgas, Częstochowa, Legnica, Nitra, Plzen, Rijeka, Split, Usti nad Labem; small cities: Banska Bystrica, Bolatice, Breclav, Cesky Tesin, Cherven Bryag, Debrecen, Decin, Galanta, Gbely, Gheorgheni, Hodonin, Hradec Kralove, Hranice, Jablonec nad Nisou, Jászfényszaru, Jihlava, Kamenice, Karlovy Vary, Lazuri, Lesce, Letohrad, Logatec, Medvode, Mochov, Modrice, Mogosoaia, Nyíregyháza, Ostrava, Petrvald, Piestany, Połkowice, Poznań, Ptuj, Puchov, Rokietnica, Roznava, Skawina, Stefanestii de Jos, Stefanovo, Stupava, Szczecin, Tirgu Mures, Trnava, Turna nad Budvou, Vrable Wolica, Zatec, Zlin.

2* Large city: Lódź

3* Large city: Cracow; small cities: Belisce, Koper, Liberec, Skofja Vas.

4* Large city: Wrocław; medium-sized city: Rzeszów; small cities: Kęzierzyn Koźle, Krusovice, Majosháza, Medias, Pilisszentiván, Rohoznik, Sumperk, Tarnów, Velenje.

5* Medium-sized city: Świebodzin.

Source: Zdanowska (2018), IGD-UNIL-BvD ORBIS (2013).

Regional Statistics, Vol. 10. No. 2. 2020: 3-26; DOI: 10.15196/RS100202 
Small towns (of 10,000 to 50,000 inhabitants) develop most of their linkages with post-communist, Central Eastern, and European Union areas. Most mediumsized cities (of 50,000 to 250,000 inhabitants) have CEE orientations (see Table 4). This demonstrates that large cities (above 250,000 inhabitants) are not the only ones attracting capital links from abroad: small and medium-sized cities, often thought to be left behind by globalisation (Escach-Vaudor 2014), are also present in these international networks.

Table 4

Implication of small, medium, and large CEE cities according to the orientation of their firm linkages (expressed as a percentage of total localized linkages)

\begin{tabular}{l|r|r|r|r}
\hline \multirow{2}{*}{ From cities: } & \multicolumn{4}{|c}{ Towards cities localized in: } \\
\cline { 2 - 5 } & EUa) & CEE & POST-COM ${ }^{\mathrm{b})}$ & OEc $^{\mathrm{c}}$ \\
\hline Small & 47 & 56 & 50 & 14 \\
Medium-sized & 24 & 29 & 10 & 0 \\
Large & 29 & 15 & 40 & 86 \\
Total & 100 & 100 & 100 & 100
\end{tabular}

a) European Union outside CEE. b) Post-communist. c) Outside Europe.

Source: Zdanowska (2018), IGD-UNIL-BvD ORBIS (2013).

Finally, we computed the betweenness centrality for cities in N-1 (= number of shortest paths passing through a node; Albert-Barabasi [2002]). This determines the number of times that a CEE city in N-1 is a crossing point relaying capital control links towards $\mathrm{N}-2$. The higher this centrality is for a node, the greater its importance in terms of passage and its role as a gateway between chain levels. We then checked if population size is a decisive variable in the relaying of capital control links towards the four orientations of the links in N-2 (see Table 5).

Table 5

\section{Characteristics of cities in $\mathrm{N}-1$, according to the different orientations of links in N-2}

\begin{tabular}{l|c|c|c|c}
\hline & \multicolumn{4}{|c}{ Among links oriented in N-2 towards cities located in: } \\
\hline $\mathrm{R}^{2}$ in N-1 between & EU & CEE & POST-COM & OE \\
POP \& BETWEENNESS & 0.75 & 0.41 & 0.15 & 0.24
\end{tabular}

Source: Zdanowska (2018), IGD-UNIL-BvD ORBIS (2013).

Regarding the links oriented toward the European Union outside CEE countries in $\mathrm{N}-2$, the relationship between population and betweenness centrality is statistically significant $\left(\mathrm{R}^{2}=0.75\right)$. However, this relationship is much less significant for the Central Eastern and non-European orientations (0.41 and 0.24), and not at all significant for post-communist areas $\left(\mathrm{R}^{2}=0.15\right.$; see Table 5$)$.

It can be inferred that the role of small and medium-sized cities is important in all orientations, except those towards the rest of the European Union, which shows 
the importance of considering these links and including small and medium-sized cities in globalised networks.

\section{Conclusion}

The confrontation of several complex system processes leads to a deeper understanding of current trends within the Central and Eastern European system of cities. Between integration and diffusion the urban system faces both rapid changes and path-dependent forces.

Despite lacking very large cities, the CEE urban system is hierarchized by international functions more strongly than is the Western European urban system, with a growing concentration of metropolitan functions according to city size. Metropolisation forces are strong because they are in an earlier stage of global integration than Western cities are. However, aside from the size effect, the participation of Eastern cities in globalisation networks also depends on their distance to Western borders. In addition, historical specialisations confer to some small and medium-sized cities a more important role than would be expected in the network of multinational firms, which confirms the necessity of considering small and medium-sized cities in globalised network analysis. The capital investments generated from multinational firms between the largest cities and small and medium-sized cities inside the CEE are key factors of integration via globalisation. This stepwise integration is strongly influenced by the remaining historical linkages between CEE and post-communist cities, and much less intensively to other countries outside Europe. It is taking a long time for the CEE urban system to recompose inside the capitalist system, and the emerging complexity is largely based on long-term spatial, cultural, and political proximities, including the great importance of Western Europe through EU integration. This ongoing process of EU integration amid the general globalisation trend in the CEE urban economies demonstrates how changes can occur relatively quickly, over a period of 30 years through intense policies undertaken by the EU commission. A wide gap still separates Western and Eastern cities' development regarding metropolisation processes. This gap is due to the time lag in the urban system's adaptive cycle and from structural differences (i.e. the path-dependence of the dynamics), which will probably ensure the continued distinct development of the CEE's urban system. The relaunch of European cohesion policies in the new program after 2020 has taken this issue into account and will probably reduce the gap and enhance integration.

Regional Statistics, Vol. 10. No. 2. 2020: 3-26; DOI: 10.15196/RS100202 


\section{REFERENCES}

Albert, R.-BARABÁsI, A. L. (2002): Statistical mechanics of complex networks Reviews of Modern Physics 74 (1): 47. https://doi.org/10.1103/RevModPhys.74.47

Arcaute, E.-Hatna, E.-Ferguson, P.-Youn, H.-Johansson, A.-Batty, M. (2015): Constructing cities, deconstructing scaling laws Journal of The Royal Society Interface 12 (102): 20140745. https://doi.org/10.1098/rsif.2014.0745

ATKINSON, R. (2019): The Small Towns conundrum: What do we do about them? Regional Statistics 9 (2): 3-19. https://doi.org/10.15196/RS090201

BAtTy, M.-LOngley, P. (1994): Fractal cities: a geometry of form and function Academic Press, London.

BAUDET-Michel, S. (2001): Un siècle de diffusion des services aux entreprises dans les systèmes urbains français, britannique et ouest-allemand L'Espace Géographique 30 (1): 53-66. https://doi.org/10.3917/eg.301.0053

BERTAUD, A. (2004): The spatial organization of cities: Deliberate outcome or unforeseen consequence? Escholarship.org., Working Paper 2004-01, Institute of Urban and Regional Development University of California at Berkeley, Berkeley, CA.

Bettencourt, L.-West, G. (2010): A unified theory of urban living Nature 467 (7318): 912. https://doi.org/10.1038/467912a

Bleicher, H. (1892): Statische Beschreibung der Stadt Frankfurt am Main und ihrer Bevolkerung Zeitschrift für die gesamte Staatswissenschaft / Journal of Institutional and Theoretical Economics 53 (2): 340-350.

Bretagnolle, A.-Pumain, D.-Rozenblat C. (1998): Space-time contraction and the dynamics of urban systems Cybergeo : European Journal of Geography Document 61. https://doi.org/10.4000/cybergeo.2420

Bretagnolle, A.-Mathian H.-Pumain, D.-Rozenblat, C. (2000): Long-term dynamics of European towns and cities: towards a spatial model of urban growth Cybergeo, European Journal of Geography Document 131. https://doi.org/10.4000/cybergeo.566

Bretagnolle, A.-Pumain, D. (2010) : Simulating urban networks through multiscalar space-time dynamics: Europe and the United States, 17th-20th centuries Urban Studies 47 (13): 2819-2839. https://doi.org/10.1177/0042098010377366

CatTan, N. (ed.) (2007): Cities and networks in Europe: A critical approach of polycentrism John Libbey Eurotex.

Cattan, N.-Pumain, D.-Rozenblat, C.-Saint-Julien, TH. (1994): Le système des villes européennes Anthropos, Paris.

Christaller, W. (1933): Die Zentralen Orte in Süddeutschland: eine Ökonomisch-Geographische Untersuchung Über die Gesetz. Massigkeit der Verbreitung und Entwicklung der Siedlungen mit Städitschen Funktionen Fischer Verlag, Jena.

Clark, C. (1951): Urban population densities Journal of the Royal Statistical Society 114 (4): 490-496. https:/ / doi.org/10.2307/2981088

COTTINEAU, C. (2014): L'évolution des villes dans l'espace post-soviétique. Observation et modélisations Thèse de doctorat en Géographie, Université Paris 1 Panthéon-Sorbonne.

Regional Statistics, Vol. 10. No. 2. 2020: 3-26; DOI: 10.15196/RS100202 
CsETE, M.-SZABÓ, M. (2014): How spatial distribution of the Hungarian TOP 500 companies affects regional development: an examination of income generation at subnational level Regional Statistics 4 (1): 30-40. http://dx.doi.org/10.15196/RS04104

D'ARCY THOMPSON, W. (1952): On growth and form Cambridge University Press, Cambridge.

Denis, E. (2020): Population, Land, Wealth and the Global Urban Sprawl. Drivers of urban built-up expansion across the world from 1990 to 2015. In: Pumain, D. (ed): Theories and models of urbanization pp. 236-258., Springer, Cham. https://doi.org/10.1007/978-3-030-36656-8

DE VRIES (1984): European Urbanization 1500-1800 Methuen, London.

Di Lello, O.-Rozenblat, C. (2014): Les réseaux de firmes multinationales dans les villes d'Europe centre-orientale Cybergeo: European Journal of Geography Document 678. http://dx.doi.org/10.4000/cybergeo.26325

Drbohlav, D. (2003): Immigration and the Czech Republic (with a Special Focus on the Foreign Labor Force) International Migration Review 37 (1): 194-224. https://doi.org/10.1111/j.1747-7379.2003.tb00134.x

DZIEWOŃSKI, K. (1953): Geografia miast i osiedli w Polsce Wiedza Powszechna, Warszawa.

ENYEDI, GY. (1996): Urbanization under socialism. In: ANDRUSZ, G.-HARLOE, M.SZELENYI, I. (eds.): Cities after Socialism: Urban and regional change and conflict in post-socialist societies pp. 100-118., Blackwell, Oxford.

EsCACH, N.-VAudor, L. (2014): Réseaux de villes et processus de recomposition des niveaux : le cas des villes baltiques Cybergeo: European Journal of Geography Document 679. https://doi.org/10.4000/cybergeo.26336

ESPON (2010): FOCI - Future Orientation for Cities (Report). Luxemburg.

FINANCE, O. (2016) : Les villes françaises investies par des capitaux étrangers : des entreprises en réseaux aux établissements localisés Thèse de doctorat, University Paris I, Paris.

FrankHAuser, P. (1994): La fractalité des structures urbaines Anthropos, Collection Villes, Paris.

Gerohazi, E.-Hegedüs, J.-Szemzo, H.-Tomay, K.-Tosics, I.-Gere, L. (2011): The impact of European demographic trends on regional and urban development Regional Statistics 1 (1): 80-98.

GuÉROIS, M. (2003): Les formes des villes européennes vues du ciel Thèse de doctorat. Université Paris I.

GuÉrois, M.-Pumain, D. (2008): Built-up encroachment and the urban field: a comparison of forty European cities Environment and Planning A 40 (9): 2186-2203. https://doi.org/10.1068/a39382

Guerois, M.-Bretagnolle, A.-Gourdon, P.-Pavard, A.-Zdanowska, N. (2019): Following the population of European urban areas in the last half century (19612011): the TRADEVE database Cybergeo European Journal of Geography Document 891. https://doi.org/10.4000/cybergeo.32034

Hägerstrand, T. (1952): The propagation of innovation waves Lund Studies in Geography: Series B, Human Geography 4: 18-19.

Hald, P. G.-PAIN, K. (2006): The Polycentric Metropolis: Learning from Mega-City Regions in Europe. Routledge.

HoHenberg, P.-LEes, L. (1995): The making of urban Europe, 1000-1994 Harvard University Press, Cambridge, MA.

Regional Statistics, Vol. 10. No. 2. 2020: 3-26; DOI: 10.15196/RS100202 
IGD-UNIL-BvD ORBIS (2013): Orbis database.

JANELLE, D. G. (1969): Spatial reorganization: a model and concept Annals of the Association of American Geographers 59 (2): 343-368. https://doi.org/10.1111/j.1467-8306.1969.tb00675.x

KACZMARCZYK, P.-OKÓlSKI, M. (2005): International migration in Central and Eastern Europe current and future trends United Nations Secretariat Publications, New York.

KISS, E. (2004): Spatial impacts of post-socialist industrial transformation in the major Hungarian cities European Urban and Regional Studies 11 (1): 81-87.

KoHL, J. G. (1841): Der Verkehr und die Ansiedelungen der Menschen in ibrer Abhängigkeit des Gestaltung der Erdoberfläche Arnold, Dresden/Leipzig.

KorCELli, P. (1992): International Migrations in Europe: Polish Perspectives for the 1990s International Migration Review 26 (2 Special Issue: The New Europe and International Migration): 292-304. https://doi.org/10.1177/019791839202600206

KovÁCs, Z. (2004): The socio-economic transition and regional differentiation in Hungary Hungarian Geographical Bulletin 53 (1-2): 33-49.

LAne, D.-Pumain, D.-VAN DeR Leeuw, S.-WeSt, G. (2009): Complexity perspectives on Innovation and Social change Springer, Haarlem. https://doi.org/10.1007/978-1-4020-9663-1

LENGYel, I.-SZAKÁlné KanÓ, I. (2012): Competitiveness of Hungarian Urban Microregions: Localization Agglomeration Economies and Regional Competitiveness Function Regional Statistics 2 (1): 27-44. http://dx.doi.org/10.15196/RS02103

MARTINEZ-FERnANDEZ, C.-AudiraC, I.-Fol, S.-CunNingHAM-SABOT, E. (2012): Shrinking cities: Urban challenges of globalization International Journal of Urban and Regional Research 36 (2): 213-225. https://doi.org/10.1111/j.1468-2427.2011.01092.x

MÁTÉ, G.-KoVÁCS, A.-NÉDA, Z. (2013): Hierarchical Settlement Networks Regional Statistics 3 (1): 30-40. http://dx.doi.org/10.15196/RS03102

McGee, T. G. (2009): The Spatiality of Urbanization: The Policy Challenges of Mega-Urban and Desakota Regions of Southeast Asia United Nations University Institute of Advanced Studies, Working Paper (161) Tokyo.

MORICONI-EBRARD, F. (1993): Géopolis: pour comparer les villes du monde Anthropos, Paris.

Musil, J. (1977): Urbanizace v socialistických zemich Svoboda, Praha.

Noworól, A.-Noworól, K.-HA£AT, P. (2010): Program Rewitalizacji Obszarów Miejskich w Rzeszowie na lata 2007-2015 report, Alexander Noworól Konsulting, Warszawa.

PÁTHY, Á. (2017): Types of development paths and the hierarchy of the regional centres of Central and Eastern Europe Regional Statistics 7 (2): 124-147. https://doi.org/10.15196/RS070202

PAulus, F. (2004): Coévolution dans les systèmes de villes: croissance et spécialisation des aires urbaines françaises de 1950 à 2000 Thèse de doctorat, Université Paris 1, Paris.

Paulus, F.-Pumain, D. (2000): Trajectoires de villes dans le système urbain. In: Pumain, D.-Mattei, M.-F. (dir.): Données urbaines 3 pp. 363-372., Anthropos, Paris.

Peris, A-Meijers, E.-VAn Ham, M. (2018): The Evolution of the Systems of Cities Literature since 1995: Schools of Thought and their Interaction Networks and Spatial Economics 18 (3): 533-554. https://doi.org/10.1007/s11067-018-9410-5

Regional Statistics, Vol. 10. No. 2. 2020: 3-26; DOI: 10.15196/RS100202 
PRED, A. R. (1973): Urban Growth and the Circulation of Information: the United States System of Cities, 1790-1840. Oxford University Press, London.

PRED, A. R. (1977): City systems in advanced societies Hutchison, London.

PuMAIN, D. (1997): Vers une théorie évolutive des villes L'Espace Géographique 26 (2): 119-134.

Pumain, D. (2012): Urban systems dynamics, urban growth and scaling laws: The question of ergodicity. In: Portugali, J.-Meyer, H.-STOLK, E.-TAN, E. (eds.): Complexity theories of cities have come of age pp. 91-103., Springer, Berlin-Heidelberg.

Pumain, D. (2018): An Evolutionary Theory of Urban Systems. In: Rozenblat, C.Pumain, D.-VelasqueZ, E.: International and Transnational Perspectives on Urban Systems pp. 3-18., Springer Nature, Advances in Geographical and Environmental Sciences, Singapore. https://doi.org/10.1007/978-981-10-7799-9

Pumain, D.-PAulus, F.-VACChIANI, C.-LOBO, J. (2006): An evolutionary theory for interpreting urban scaling laws Cybergeo, European Journal of Geography Document 343. https://doi.org/10.4000/cybergeo.2519

Pumain, D.-SAint-Julien, TH. (eds.) (1996): Urban networks in Europe John Libbey-INED, Congresses and Colloquia, 15, Paris.

Pumain, D.-Moriconi-Ebrard, F. (1997): City Size distributions and metropolisation Geojournal 43 (4): 307-314. https://doi.org/10.1023/A:1006833025206

Pumain, D.-Rozenblat, C. (2019). Two metropolisation gradients in the European system of cities revealed by scaling laws Environment and Planning B: Urban Analytics and City Science 46 (9): 1645-1662. https://doi.org/10.1177/2399808318785633

Pumain, D.-Swerts, E.-Cottineau， C.-VACchiani-Marcuzzo, C.-Ignazzi, A.Bretagnolle, A.-Delisle, F.-CurA, R.-Lizzi, L.-BAfFi, S. (2015): Multilevel comparison of large urban systems Cybergeo: European Journal of Geography Document 706. https://doi.org/10.4000/cybergeo.26730

RECHNITZER, J.-BERKES, J.-FILEP, B. (2019): The most important city development initiatives of Hungary Regional Statistics 9 (2): 20-44. https://doi.org/10.15196/RS090204

ReYNAud, J. (1841): Villes Encyclopédie nouvelle VIII.: 670-687., Gosselin, Paris.

RoBIC, M.-C. (1982): Cent ans avant Christaller, une théorie des lieux centraux L'Espace Géographique 1: 5-12.

ROBSON, B. (1973): Urban growth, an approach Methuen, London.

Rozenblat, C. (1995): Tissu d'un semis de villes européennes Mappemonde (4): 22-27.

Rozenblat, C. (2009): European urban polycentrism: a multiscale typology Geographica Helvetica (3): 175-185. https://doi.org/10.5194/gh-64-175-2009

Rozenblat, C.-Cicille, P. (2003): Les villes européennes, analyse comparative DATAR - La Documentation française, Paris.

Rozenblat, C.-MElanÇON, G. (eds.) (2013): Methods for multilevel analysis and visualisation of geographical networks Springer Netherlands, Hague. https://doi.org/10.1007/978-94-007-6677-8

Rozenblat, C.-Pumain, D. (1993): The location of multinational firms in the European urban system Urban Studies 30 (10): 1691-1709.

https://doi.org/10.1080/00420989320081671

Regional Statistics, Vol. 10. No. 2. 2020: 3-26; DOI: 10.15196/RS100202 
Rozenblat, C.-Pumain, D. (2007): Firm linkages, innovation and the evolution of urban systems. In: TAYLOR et al. (eds.): Cities in globalization: Practices, policies, theories pp. 130-156., Routledge, London.

Rozenblat, C.-Pumain, D. (2018): Metropolization and polycentrism in the European Urban system. In: ROZENBLAT, C.-PUMAIN, D.-VELASQUEZ, E.: International and Transnational Perspectives on Urban Systems pp. 117-138., Springer Nature, Advances in Geographical and Environmental Sciences, Singapore. https://doi.org/10.1007/978-981-10-7799-9

RYBSKI, D.-ARCAUTE, E.-BATTY, M. (2019): Urban scaling laws Environment and Planning B 46 (9) : 1603-1768. https://doi.org/10.1177/2399808319886125

SZIRMAI, V. (2012): Urban Sprawl in Europe Regional Statistics 2 (1): 129-148.

UN-HABITAт (2016): World cities report, urbanization and development, emerging futures United Nations Human Settlements Programme (UN-Habitat), Nairobi, Kenya.

United Nations (2014): Revision of the World Urbanization Prospect. https://www.un.org/en/development/desa/publications/2014-revision-worldurbanization-prospects.html

West, G. B.-BROWN, J. H.-EnQuist, B. J. (1997): A general model for the origin of allometric scaling laws in biology Science 276 (5309): 122-126. https://doi.org/10.1126/science.276.5309.122

WEST, G. B. (2017): Scale: the universal laws of growth, innovation, sustainability, and the pace of life in organisms, cities, economies, and companies Penguin Press, London.

WORLD BANK (2009): Annual Report Washington.

ZELINSKY, W. (1971): The hypothesis of the mobility transition Geographical Review 61 (2): 219-249. https://doi.org/10.2307/213996

ZDANOwSKA, N. (2015): Metropolisation and the Evolution of Systems of Cities in the Czech Republic, Hungary and Poland Since 1950 Deturope - The Central European Journal of Regional Development and Tourism 7 (2): 45-64.

ZDANowsKa, N. (2016): Métropolisation et système de villes en Pologne depuis 1960 Revue Géographique de l'Est 56 (3-4). http:/ / rge.revues.org/5891

ZDANOWSKA, N. (2018): Intégration des villes d'Europe centrale et orientale dans l'économie-monde par les réseaux internationaux de commerce, de transport aérien et de firmes $\mathrm{PhD}$ dissertation, Université Paris 1 Panthéon-Sorbonne, Paris.

Regional Statistics, Vol. 10. No. 2. 2020: 3-26; DOI: 10.15196/RS100202 